\title{
EFFECTS OF NANO-Fe $\mathrm{O}_{4}$ AND HYDROGEN SULFIDE ON ALLEVIATING HEAVY METAL TOXICITY IN CUCUMBER SEEDLING
}

\author{
QIAO, L.*-LIU, H. - HU, C. - HU, L. - DU, H. \\ College of Life Science and Agronomy, Zhoukou Normal University, Zhoukou 466001, China \\ *Corresponding author \\ e-mail:qiaolin2012@126.com \\ (Received $15^{\text {th }}$ Sep 2018; accepted $12^{\text {th }}$ Nov 2018)
}

\begin{abstract}
The possible role of reducing effects of nano- $\mathrm{Fe}_{3} \mathrm{O}_{4}$ and hydrogen sulfide on alleviating heavy metal toxicity in germinating cucumber seedling was investigated. The toxic effects of $\mathrm{Fe}_{3} \mathrm{O}_{4}$ nanoparticles (NPs) $(6,50,100 \mathrm{~nm})$, and bulk were evaluated in cucumber plants. Among the synthesized nano- $\mathrm{Fe}_{3} \mathrm{O}_{4}$, only the small size $(6 \mathrm{~nm})$ had significant inhibit effect on fresh and dry biomass of cucumber seedlings. cucumber seedlings grown under lowest concentrations of $50 \mathrm{mg} / \mathrm{L}$ nano- $-\mathrm{Fe}_{3} \mathrm{O}_{4}(6$ $\mathrm{nm})$ were affected by a decrease in biomass and enzyme activities compared to control. However, at higher concentration of nano- $\mathrm{Fe}_{3} \mathrm{O}_{4}$ dosage $(2000 \mathrm{mg} / \mathrm{L})$, there was significant increase in biomass and enzymatic activities of superoxide dismutase (SOD) and peroxidase (POD), respectively. The toxicity effects of the different sizes of nano- $\mathrm{Fe}_{3} \mathrm{O}_{4}$ particles and bulk- $\mathrm{Fe}_{3} \mathrm{O}_{4}$ might depend on the chemical composition, the structure properties/ particle sizes, the concentration in the tested medium, the time of incubation, as well as the plant species.
\end{abstract}

Keywords: heavy metal toxicity, toxic mechanism, magneto dipole interaction, nano- $\mathrm{Fe}_{3} \mathrm{O}_{4}$, cucumber seedling

\section{Introduction}

Due to the anticipated high-volume production and widespread use in coming years, engineered nano-materials will inevitably be released into the environment and interact with plants during manufacture, use, and disposal. Magnetic $\left(\mathrm{Fe}_{3} \mathrm{O}_{4}\right)$ nanoparticles have been widely investigated for their scientific interests but also their technological application in many fields (ferrofluids, biomedicines, magnetic records, catalysts and electronic technique) due to their biological compatibility and magnetic properties (Shen et al., 2013). Iron oxide nanoparticles are among the primary nano-materials used in biomedical fields due to their magnetic property and high chemical stability (Xiao et al., 2011). Co-precipitation method and high-temperature decomposition are the two methods commonly used to prepare iron oxide nanoparticles. However, reactions of coprecipitation do not furnish excellent control of size distribution and crystallinity of the resulting particles; they are also thermodynamically driven (Laurent et al., 2008; Vinod et al., 2012; Jain et al., 2008). On the other hand, the use of FeOx NPs produced with high-temperature decomposition reactions of metal-organic compounds is limited because they are soluble only in organic solvents. The preparation of water-dispersible iron oxide nanoparticles with suitable surface coatings provides a major challenge in nanotechnology. In the present study, we synthesized water-soluble small iron oxide nanoparticles by the chemical reduction method using vitamin $\mathrm{C}$ as the reducing agent by oxidizing its $\mathrm{C}=\mathrm{C}$ double bond. It has been reported that the magnetic property of magnetic $\left(\mathrm{Fe}_{3} \mathrm{O}_{4}\right)$ nanoparticles could depend on their particle sizes (Roca et al., 2007). The polyol-mediated method is a versatile chemical system to prepare excellent-quality 
water-stable $\mathrm{Fe}_{3} \mathrm{O}_{4}$ nanoparticles (Shen et al., 2013). In this synthesis approach, polyols (ethylene glycol (EG), diethylene glycol (DEG), triethylene glycol or poly-ethylene glycol) are usually used as solvent and reductant and play a stabilizer role to control the growth of particles and prevent inter-particle aggregation (Liu et al., 2009; MiguelSancho et al., 2011). Magnetic $\left(\mathrm{Fe}_{3} \mathrm{O}_{4}\right)$ nanoparticles synthesized with this method can exhibit some water dispersibility, compared to the thermal decomposition method. This might be dependent on the hydrophilic coating (Liu et al., 2009). In the present work, the polyol-mediated method was used as the second method to prepare magnetic $\left(\mathrm{Fe}_{3} \mathrm{O}_{4}\right)$ nanoparticles: $50 \mathrm{~nm}$ and $100 \mathrm{~nm}$, using ethylene glycol (EG) as the solvent and reductant. The TEM images, XRD, vibrating sample magnetometer (VSM), Fourier transform infrared (FTIR) spectroscopy and thereto gravimetric analyses (TGA) were used in this study to characterize the synthesized nanoparticles and bulk. The aim of this paper is to research on the effects of nano- $\mathrm{Fe}_{3} \mathrm{O}_{4}$ and hydrogen sulfide on alleviating heavy metal toxicity in germinating cucumber seedling.

\section{Materials and Methods}

Photosynthesis of cucumber can be best accumulated at $25 \sim 32{ }^{\circ} \mathrm{C}$. During the morning, the temperature should be maintained at around $25^{\circ} \mathrm{C}$, and the temperature will be slightly reduced in the afternoon. Carbon dioxide fertilized in the morning. In order to promote nutrient transport and reduce plant consumption, the temperature should be controlled in the first half of the night at $16-18{ }^{\circ} \mathrm{C}$ and in the second half of the night at $10-14{ }^{\circ} \mathrm{C}$. The optimum temperature for root growth is $20 \sim 23{ }^{\circ} \mathrm{C}$, the lowest temperature is $8 \sim 12{ }^{\circ} \mathrm{C}$, and the highest temperature is $32 \sim 38{ }^{\circ} \mathrm{C}$. The temperature of root growth is no less than $15^{\circ} \mathrm{C}$.

\section{Chemicals}

Different chemicals were used to synthesize different sizes of magnetic $\left(\mathrm{Fe}_{3} \mathrm{O}_{4}\right)$ nanoparticles. In general, ferric chloride hexahydrate $\left(\mathrm{FeCl}_{3} \cdot 6 \mathrm{H}_{2} \mathrm{O}\right)$, sodium hydrogen carbonate $\left(\mathrm{NaHCO}_{3}\right)$, ascorbic acid or vitamin $\mathrm{C}\left(\mathrm{C}_{6} \mathrm{H}_{8} \mathrm{O}_{6}\right)$, ethylene glycol $\mathrm{C}_{2} \mathrm{H}_{6} \mathrm{O}_{2}$, 1,6-Hexanediamine $\left(\mathrm{C}_{6} \mathrm{H}_{16} \mathrm{~N}_{2}\right)$, and sodium acetate $\left(\mathrm{CH}_{3} \mathrm{COONa}\right)$, also abbreviated NaOAc were used as shown in the Table 1 to synthesize nanoparticles of 6, 50 and 100 nm sizes.

Table 1. Chemicals used to synthesis nano- $\mathrm{Fe}_{3} \mathrm{O}_{4}(6 \mathrm{~nm}, 50 \mathrm{~nm}$, and $100 \mathrm{~nm})$

\begin{tabular}{|c|c|c|c|c|c|c|c|}
\hline \multirow[t]{2}{*}{$\mathbf{N}$} & \multicolumn{4}{|c|}{ Chemical composition } & \multicolumn{3}{|c|}{ Autoclave } \\
\hline & & & & & $\begin{array}{c}\text { Temperature } \\
\left({ }^{\circ} \mathrm{C}\right)\end{array}$ & $\begin{array}{l}\text { Time } \\
(\mathrm{min})\end{array}$ & $\begin{array}{l}\text { Size } \\
(\mathrm{nm})\end{array}$ \\
\hline I & $\mathrm{FeCl}_{3} .6 \mathrm{H}_{2} \mathrm{O}(0.54 \mathrm{~g})$ & $\mathrm{NaHCO}_{3}(1.52 \mathrm{~g})$ & $\mathrm{VC}(0.06 \mathrm{~g})$ & $\mathrm{H}_{2} \mathrm{O}(35 \mathrm{ml})$ & 150 & 240 & 6 \\
\hline II & & $\mathrm{NaOAc}(2 \mathrm{~g})$ & $\begin{array}{c}1,6- \\
\operatorname{Hexa}(6.7 \mathrm{ml})\end{array}$ & & 198 & & 50 \\
\hline & $\mathrm{FeCl}_{3} .6 \mathrm{H}_{2} \mathrm{O}(1 \mathrm{~g})$ & & & $\mathrm{EG}(30 \mathrm{ml})$ & & 360 & \\
\hline III & & $\mathrm{NaOAc}(1 \mathrm{~g})$ & $\begin{array}{c}1,6- \\
\mathrm{Hexa}(7 \mathrm{ml})\end{array}$ & & 205 & & 100 \\
\hline
\end{tabular}

The mini-Q quality water was used for all reactions and preparation procedures. All glassware used in the synthesis processes of magnetic $\left(\mathrm{Fe}_{3} \mathrm{O}_{4}\right)$ nanoparticles were 
thoroughly cleaned several times in aqua regia $\left(\mathrm{HCl}: 3\right.$ parts and $\mathrm{HNO}_{3}: 1$ part); then rinsed with water mini-Q and dried at $60{ }^{\circ} \mathrm{C}$ before being used (Burman et al., 2004; Garg et al., 2006).

\section{The Magnetic $\left(\mathrm{Fe}_{3} \mathrm{O}_{4}\right)$ Nanoparticles}

Magnetic $\left(\mathrm{Fe}_{3} \mathrm{O}_{4}\right)$ nanoparticles $(6 \mathrm{~nm})$ were synthesized following the procedure from Xiao et al. (2011), with some modification (Figure 1). In a typical $\mathrm{Fe}_{3} \mathrm{O}_{4}$ nanoparticles, a $15 \mathrm{~mL}$ of $0.54 \mathrm{~g}\left(\mathrm{FeCl}_{3} .6 \mathrm{H}_{2} \mathrm{O}\right)$ aqueous solution was first vigorously mixed with $20 \mathrm{~mL}$ of $1.52 \mathrm{~g} \mathrm{NaHCO}_{3}$ aqueous solution, then the mixture solution was stirred for $30 \mathrm{~min}$ to form a yellow solution. About $0.06 \mathrm{~g}$ of vitamin $\mathrm{C}$ was added into the first solution and the mixture stirred for $10 \mathrm{~min}$ before being transferred into an autoclave that was kept at $150{ }^{\circ} \mathrm{C}$ for $4 \mathrm{~h}$. After being allowed to cool at a room temperature, the black products were collected by magnetic separation and washed three times with water (Millipore, resistivity $>18.2 \mathrm{M} \Omega . \mathrm{cm}^{-1}$ ) and ethanol. The residue obtained was dried at $60{ }^{\circ} \mathrm{C}$ before being analyzed and used.

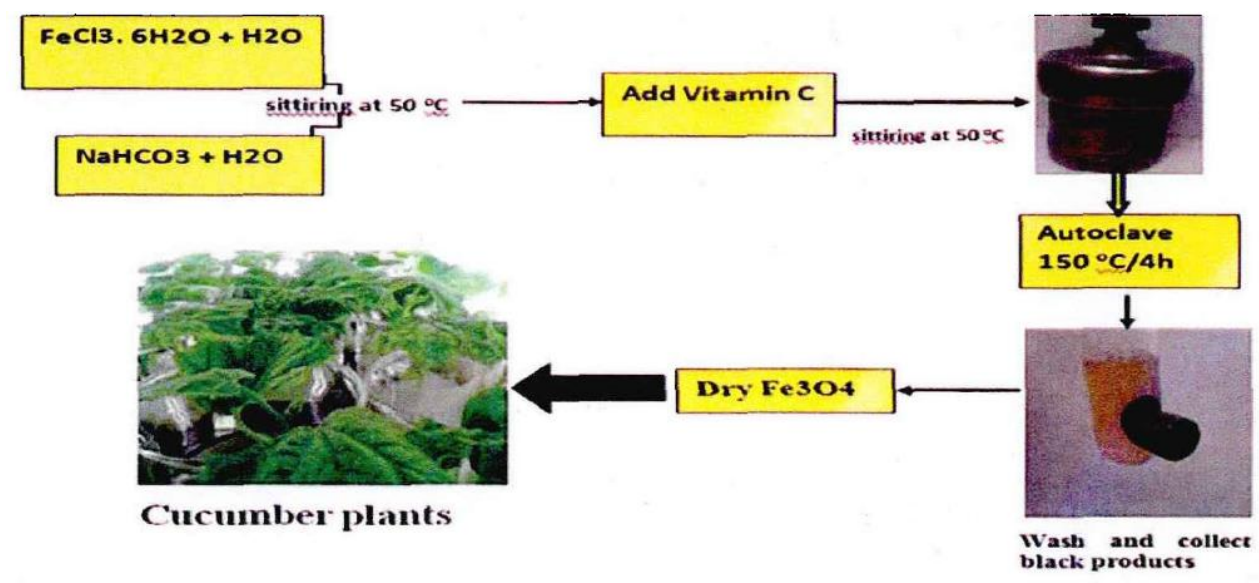

Figure 1. Synthesis procedures of magnetic $\left(\mathrm{Fe}_{3} \mathrm{O}_{4}\right)$ nanoparticles $(6 \mathrm{~nm})$

Magnetic $\left(\mathrm{Fe}_{3} \mathrm{O}_{4}\right)$ nanoparticles $(50 \mathrm{~nm}$ and $100 \mathrm{~nm})$ were synthesized following some modification of the procedures from Yin et al. (2013). For $\mathrm{Fe}_{3} \mathrm{O}_{4}(50 \mathrm{~nm}), 1 \mathrm{~g}$ $\left(\mathrm{FeCl}_{3} \cdot 6 \mathrm{H}_{2} \mathrm{O}\right)$ and $2 \mathrm{~g}(\mathrm{NOAc})$ were first vigorously mixed with $30 \mathrm{~mL}$ of $\mathrm{EG}$ (Ethylene glycol). Then $6.5 \mathrm{~mL}$ of 1,6-hexanediamine was added into the first solution and the mixture stirred for another $10 \mathrm{~min}$ before being transferred into an autoclave that was kept at $198^{\circ} \mathrm{C}$ for $6 \mathrm{~h}$. The synthesis procedure of $50 \mathrm{~nm}$ and $100 \mathrm{~nm}$ were similar. The only difference was in the addition of $1 \mathrm{~g}$ NOAc), $7 \mathrm{~mL}$ of 1,6hexanediamine and boiled at $205^{\circ} \mathrm{C}$ for $6 \mathrm{~h}$ in the synthesis of nano- $\mathrm{Fe}_{3} \mathrm{O}_{4}(100 \mathrm{~nm})$. All procedures after autoclaving were similar to those of $\mathrm{Fe}_{3} \mathrm{O}_{4}(6 \mathrm{~nm})$.

The morphology, particle shape and structure of $\mathrm{Fe}_{3} \mathrm{O}_{4}$ NPs were determined by Scanning Electron Microscopy (SEM, S-4800, HITACHI, Japan) and Transmission Electron Microscope TEM (JEM 200CX, Japan), respectively. For TEM analysis, the $\mathrm{Fe}_{3} \mathrm{O}_{4} \mathrm{NPs}$ or bulk- $\mathrm{Fe}_{3} \mathrm{O}_{4}$ were dispersed in deionized water and sonicated for $40 \mathrm{~min}$. Then, some suspension liquid was dropped on a copper grip for Transmission Electron Microscopy (TEM) observation (Zhang et al., 2011). The TEM pictures were obtained from Tecnai G2 20 S-Twin transmission electron microscope 119 (FEI company, Japan) 
operating at $200 \mathrm{kV}$. The mean size, size distribution, and Zeta potential of $50 \mathrm{mg} / \mathrm{L}$ magnetic $\left(\mathrm{Fe}_{3} \mathrm{O}_{4}\right)$ nanoparticles or bulk-Fej04 were measured by Dynamic Light Scattering (DLS) equipment (ZETA SIZER 90, Nano series, Malvern, UK) in deionized water and nutrient solution ( $\mathrm{pH}$ 5.5). FT-IR spectra were obtained using Fourier transform infrared spectroscopy (FTIR Tensor 27, Broker, Germany) analysis. The magnetic property was determined using the vibrating sample magnetometer (VSM, 7410, Lake Shore, USA). The crystal structure of the synthesized nanoparticles or bulk was obtained by X-ray diffraction, XRD (XRD, X'pert PRO MPD, Holland) measurement. To collect 20 data from about $10{ }^{\circ} \mathrm{C}$ to $90{ }^{\circ} \mathrm{C}$, we used a continuous scanning mode. Thermo gravimetric analysis (TGA) was carried out for powder samples using a NETZSCH STA 449C thermo gravimetric analyzer.

To combat against adverse environmental heavy metal toxicity, plants have developed potential mechanisms such as enzymatic activities (SOD and POD) and the production of low molecular weight thiols. Naturally, plants show differences in their capacity of heavy metals tolerance. Some plants can grow in metal-contaminated soils with high level, while other groups could not grow even at low concentration. The fresh roots or shoots $(0.2 \mathrm{~g})$ from each treatment were homogenized with $1.8 \mathrm{~mL}$ of $0.05 \mathrm{M}$ sodium phosphate buffer ( $\mathrm{PH} 7.8$ ) under ice bath to make $10 \%$ sample compound liquid. The homogenate was centrifuged at $10.000 \mathrm{mg}$ and $4{ }^{\circ} \mathrm{C}$ for $15 \mathrm{~min}$. Then, the supernatant was used for superoxide dismutase (SOD) and MDA contents. The SOD activity was analyzed by determining the ability to inhibit the photochemical reduction of nitroblue tetrazolium at $550 \mathrm{~nm}$.

\section{Results}

Figure 2 shows the XRD patterns of the synthesized magnetic $\left(\mathrm{Fe}_{3} \mathrm{O}_{4}\right)$ nanoparticles with different sizes and bulk- $\mathrm{Fe}_{3} \mathrm{O}_{4}$.

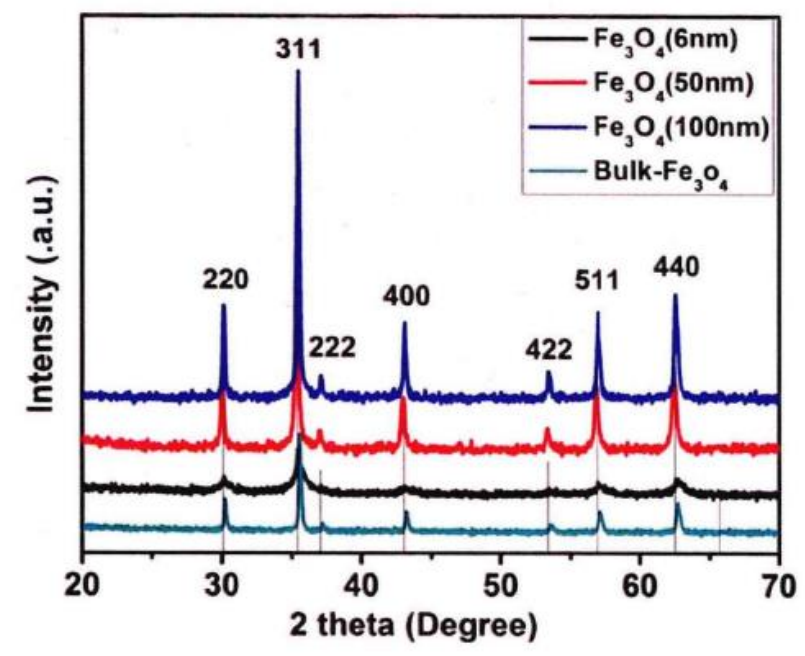

Figure 2. XRD patterns of $\mathrm{Fe}_{3} \mathrm{O}_{4}$ nanoparticles $(6 \mathrm{~nm}, 50 \mathrm{~nm}$, and $\mathrm{lOO} \mathrm{nm})$, and $\mathrm{Bulk}^{-\mathrm{Fe}_{3} \mathrm{O}_{4}}$

In this study, the characteristic peaks observed in the XRD pattern at $2 \theta$ of 30.09 , $35.42,37.05,43.05,53.39,56.94,62.51$ were corresponding to the diffractions of 220 , $311,222.400,422,511$ and 440 lattice planes of inverse cubic spinet structure of $\mathrm{Fe}_{3} \mathrm{O}_{4}$ 
NPs and $\mathrm{Fe}_{3} \mathrm{O}_{4}$-Bulk. As shown in Figure 2, all XRD patterns had a diffraction peak at $2 \theta=35.42{ }^{\circ} \mathrm{C}$ corresponding to the spinet phase of the synthesized $\left(\mathrm{Fe}_{3} \mathrm{O}_{4}\right)$ nanoparticles or bulk. The decrease in the intensity after the diffraction peaks at $2 \theta=35.42{ }^{\circ} \mathrm{C}$ could be attributed to the formulation of more crystalline phase particles in all annealed magnetic $\left(\mathrm{Fe}_{3} \mathrm{O}_{4}\right)$ nanoparticles and the bulk- $\mathrm{Fe}_{3} \mathrm{O}_{4}$. The results show that the spinet structures are in good agreement with the XRD standard for the magnetic nanoparticles and no peaks of impurities were observed in the XRD pattern, indicating that the synthesized particles powders are magnetic $\left(\mathrm{Fe}_{3} \mathrm{O}_{4}\right)$ nano-particles.

The properties of nanomaterial strongly depend upon the dimension of nanoparticles. Hence, the control of particle size is very important in nanotechnology study or nanoparticles application. In order to analyze the morphology and particles size of the synthesized magnetic $\left(\mathrm{Fe}_{3} \mathrm{O}_{4}\right)$ nanoparticles and bulk- $\mathrm{Fe}_{3} \mathrm{O}_{4}, \mathrm{SEM}$ images of particles were taken. The results are presented in the Figure 3.
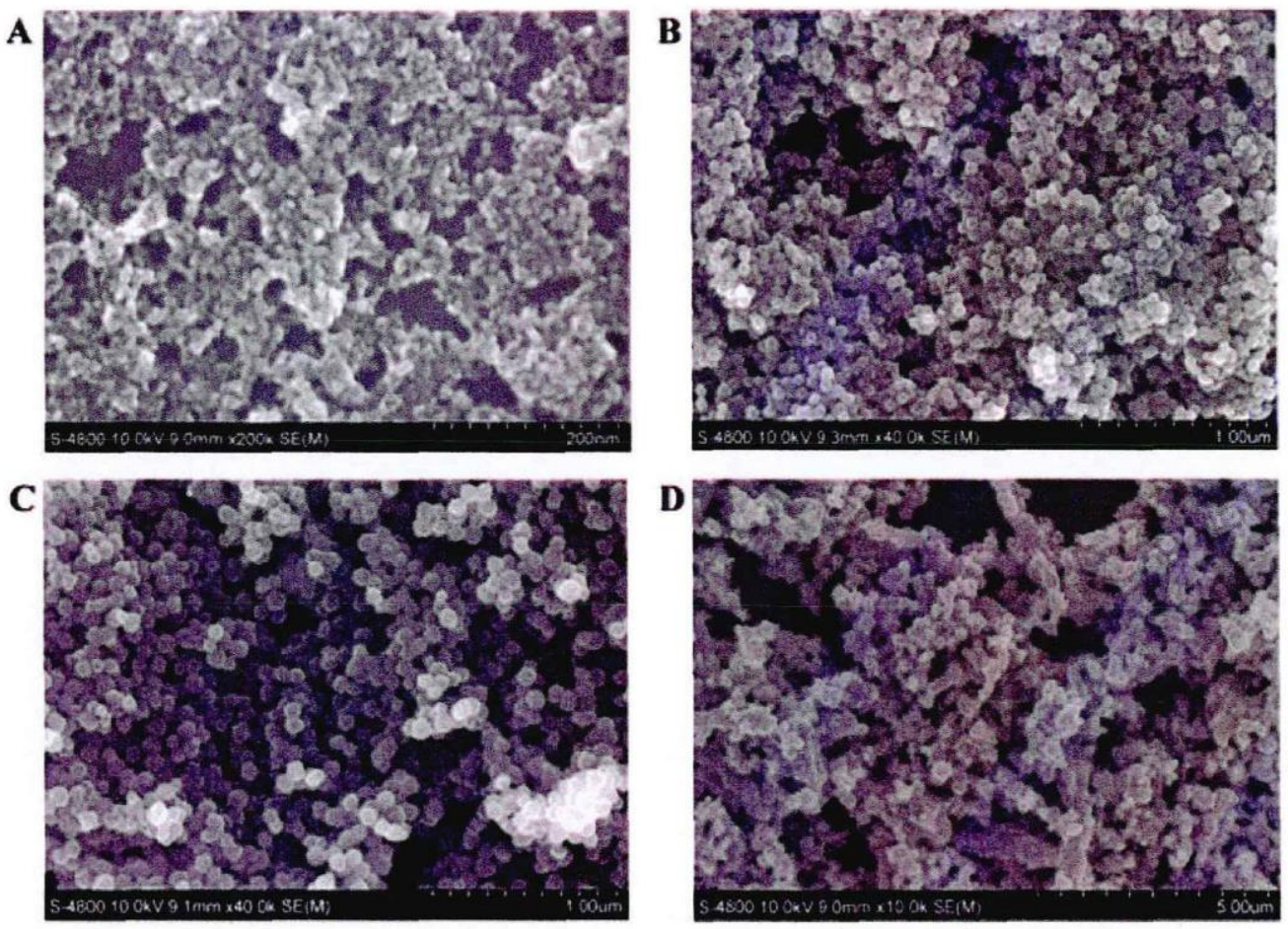

Figure 3. SEM images of $\mathrm{Fe}_{3} \mathrm{O}_{4}$ nanoparticles $6 \mathrm{~nm}(\mathrm{~A}), 50 \mathrm{~nm}(\mathrm{~B}), 100 \mathrm{~nm}(\mathrm{C})$ and bulk-Fe${ }_{3} \mathrm{O}_{4}(\mathrm{D})$

The SEM images showed that spherical magnetic $\left(\mathrm{Fe}_{3} \mathrm{O}_{4}\right)$ nanoparticles (Figure $3 A, B$ and $C$ ) were obtained from all methods of synthesis used in this study. The SEM images of the synthesized $\mathrm{Fe}_{3} \mathrm{O}_{4}$ nanoparticles (Figure 3A) showed that the materials obtained were made of small particles. As showed in Figure 3, $\mathrm{Fe}_{3} \mathrm{O}_{4}$ nanoparticles (small size) are found to be interconnected with least agglomeration which might be due to their high surface charge and the magneto dipole interaction.

\section{Discussion}

The Figure 4 shows representative TEM images of the synthesized magnetic $\left(\mathrm{Fe}_{3} \mathrm{O}_{4}\right)$ nanoparticles with diameters of $6.82 \pm 1.38 \mathrm{~nm} ; 52.56 \pm 8.01 \mathrm{~nm} ; 100.66 \pm 15.62 \mathrm{~nm}$, 
respectively. We observed that the sizes of all synthesized nanoparticles were smaller compared to bulk- $\mathrm{Fe}_{3} \mathrm{O}_{4}(144.27 \pm 28.95 \mathrm{~nm})$. The size histograms of the synthesized nanoparticles and bulk based on statistical analysis of over 90 particles are shown in the Figure $4 a-d$. The measurement of the particle diameters of all synthesized magnetic $\left(\mathrm{Fe}_{3} \mathrm{O}_{4}\right)$ nanoparticles showed a normal distribution curve after ultra-sonication dispersal as compared to bulk (Figure 4a-d). Similar observation has been reported by Shen in 2013 (Shen et al., 2013), who synthesized and characterized water-soluble ultrasmall $\mathrm{Fe}_{3} \mathrm{O}_{4}$, nanoparticles for potential bio-application.
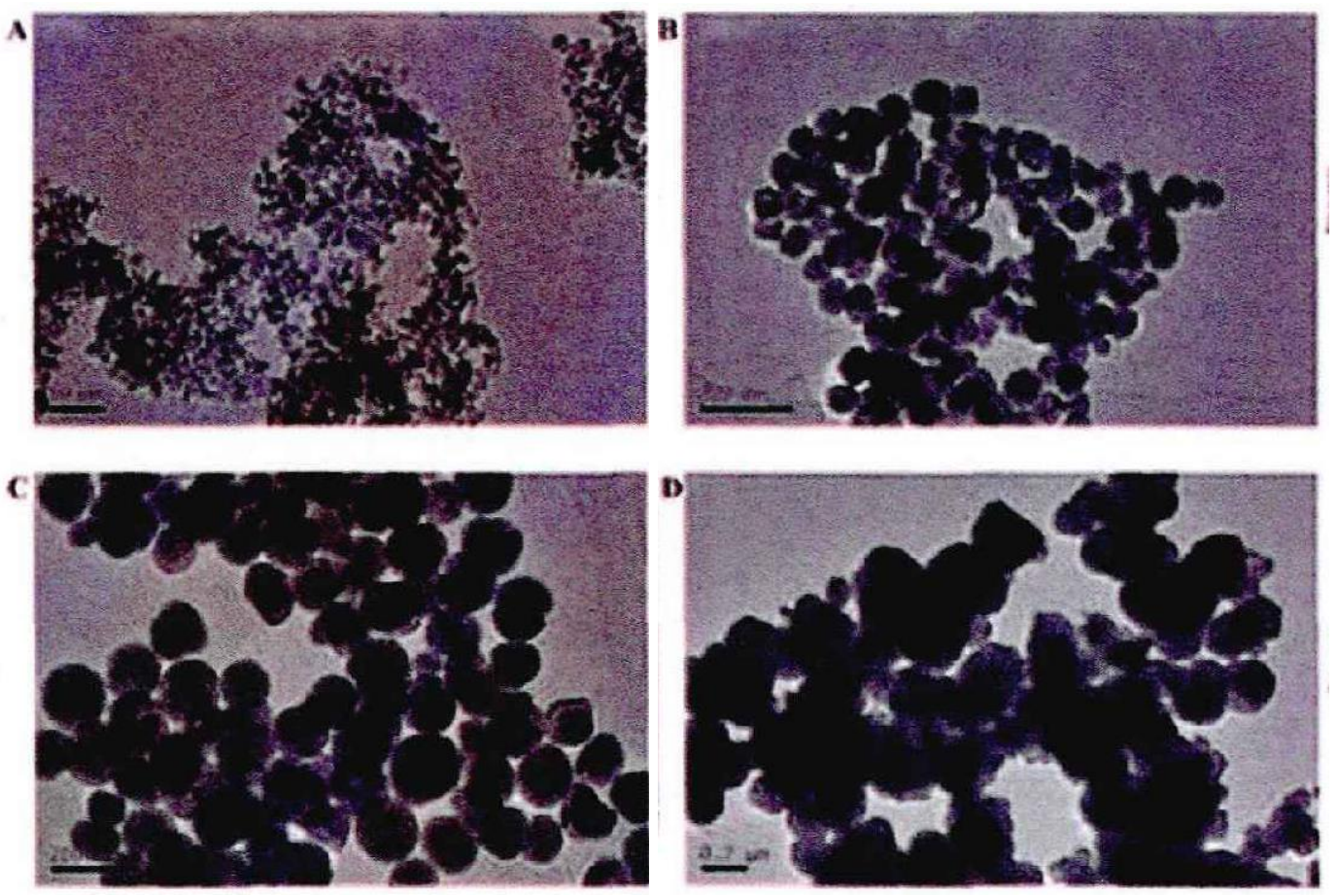

Figure 4. TEM images and size distribution histogram of $\mathrm{Fe}_{3} \mathrm{O}_{4} \mathrm{NPs}: 6 \mathrm{~nm}(\mathrm{~A}-\mathrm{a}), 50 \mathrm{~nm}(\mathrm{~B}-\mathrm{b}), 100$ $n m(C-c)$ and $\mathrm{Bulk}_{-} \mathrm{Fe}_{3} \mathrm{O}_{4},(\mathrm{D}-\mathrm{d})$

When suspended in water or nutrient solution, the hydrodynamic diameters of the 50 $\mathrm{mg} / \mathrm{L}$ of all sizes of the synthesized nanoparticles and bulk- $\mathrm{Fe}_{3} \mathrm{O}_{4}$ were larger than the results measured by their corresponding TEM images. This is due to their agglomeration. The Table 2 shows that nano- $\mathrm{Fe}_{3} \mathrm{O}_{4}$ particles were largely aggregated.

Table 2. Size distribution and zeta potentials of nano- and bulk- $\mathrm{Fe}_{3} \mathrm{O}_{4}$

\begin{tabular}{c|c|c|c|c}
\hline \multirow{2}{*}{$\begin{array}{c}\text { Nanoparticles or } \\
\text { bulk }\end{array}$} & \multicolumn{2}{|c|}{ Water } & \multicolumn{2}{c}{ Nutrient solution } \\
\cline { 2 - 5 } & $<\mathbf{D H}>\mathbf{n m}$ & $\xi$-potential $(\mathbf{m V})$ & $<\mathbf{D H}>\mathbf{n m}$ & $\xi$-potential $(\mathbf{m V})$ \\
\hline $\mathrm{Fe}_{3} \mathrm{O}_{4}(6 \mathrm{~nm})$ & $255 \pm 9.1$ & $-12.66 \pm 0.4$ & $433.3 \pm 42.2$ & $-15.9 \pm 0.2$ \\
\hline $\mathrm{Fe}_{3} \mathrm{O}_{4}(10 \mathrm{~nm})$ & $242.2 \pm 0.6$ & $27.9 \pm 0.4$ & $741.1 \pm 39.6$ & $-16.6 \pm 1.3$ \\
\hline $\mathrm{Fe}_{3} \mathrm{O}_{4}(100 \mathrm{~nm})$ & $184.7 \pm 4.1$ & $29 \pm 0.1$ & $911.5 \pm 35.3$ & $-13.5 \pm 1.1$ \\
\hline bulk- $\mathrm{Fe}_{3} \mathrm{O}_{4}$ & $1041 \pm 150.8$ & $9.8 \pm 0.6$ & $1402 \pm 118.9$ & $-18.8 \pm 0.1$ \\
\hline
\end{tabular}


In water, the aggregation level appeared in the order of $6 \mathrm{~nm}>50 \mathrm{~nm}>100 \mathrm{~nm}$ with the particles averaging $255 \pm 9.1 \mathrm{~nm}, 242.2 \pm 6.6 \mathrm{~nm}$ and $184: 7 \pm 4.1 \mathrm{~nm}$, respectively. The practical averages in nutrient solution were $433 \pm 42.2 \mathrm{~nm}, 741 \pm 39.6 \mathrm{~nm}, 911 \pm 35.3 \mathrm{~nm}$, and $1402 \pm 118.9 \mathrm{~nm}$ respectively for $6 \mathrm{~nm}, 50 \mathrm{~nm}$, and $100 \mathrm{~nm}$. The change in the order of the aggregation level $(100 \mathrm{~nm}>50 \mathrm{~nm}>6 \mathrm{~nm})$ in the nutrient solution could be due to the presence of additional chemicals in the nutrient solution. We observed that the hydrodynamic diameters of all nanoparticles were smaller in water and nutrient solution compared to bulk- $\mathrm{Fe}_{3} \mathrm{O}_{4},(1041 \pm 150.8 \mathrm{~nm}$ in water and $1402 \pm 118.9 \mathrm{~nm}$ in nutrient solution).

The modification of the synthesized magnetic $\left(\mathrm{Fe}_{3} \mathrm{O}_{4}\right)$ nanoparticles with different sizes $(6 \mathrm{~nm}, 50 \mathrm{~nm}$, and $100 \mathrm{~nm})$ and bulk- $\mathrm{Fe}_{3} \mathrm{O}_{4}$ surfaces for their stabilization were analyzed and confirmed by Fourier Transform Infrared Spectroscopy (FTIR) as shown in the Figure 5.
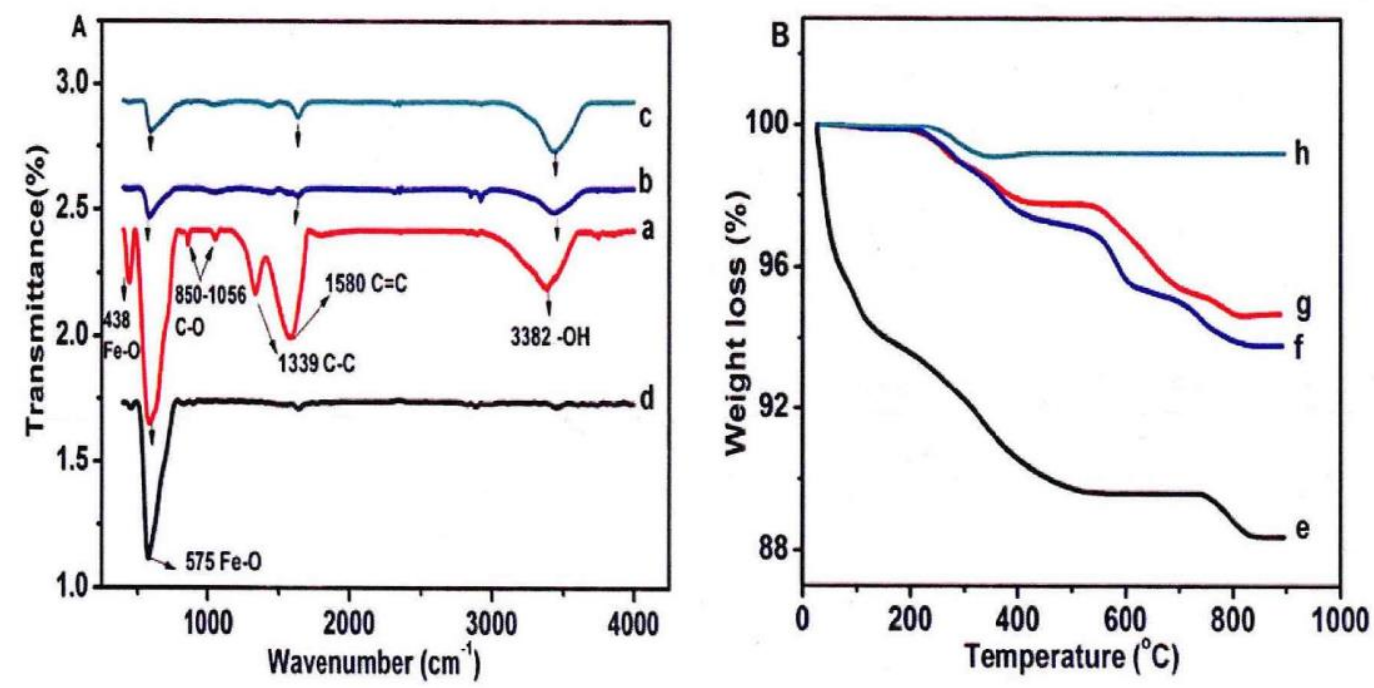

Figure 5. FTIR Analysis of $\mathrm{Fe}_{3} \mathrm{O}_{4}$, nanoparticles (Aa-c) and Bulk- $\mathrm{Fe}_{3} \mathrm{O}_{4},(\mathrm{Ad})$, TGA curves of $\mathrm{Fe}_{3} \mathrm{O}_{4}$, nanoparticles (Be-f) of bulk- $\mathrm{Fe}_{3} \mathrm{O}_{4}(\mathrm{Bh})$

In general, the stretching absorption peaks of Fe-O at $575 \mathrm{~cm}^{-1}$ appeared in the FTIR spectra of all the synthesized nanoparticles and bulk (Figure 2-SAa-d). In addition, the peaks in the region numbers $438-575 \mathrm{~cm}^{-1}$ are also attributed to the $\mathrm{Fe}-\mathrm{O}$ vibration (Figure 5). In the FTIR spectra of the nano- $\mathrm{Fe}_{3} \mathrm{O}_{4}(6 \mathrm{~nm})$, the peaks around 850-1056 $\mathrm{cm}^{-1}, 1342 \mathrm{~cm}^{-1}$ and $1580 \mathrm{~cm}^{-1}$ were related to the group $\mathrm{C}-\mathrm{O}, \mathrm{C}-\mathrm{C}$ and $\mathrm{C}=\mathrm{C}$ respectively (Figure 5). The double bonds of $\mathrm{C}=\mathrm{C}$ were due to the additional compounds, mainly the Vitamin $\mathrm{C}$ in using chemicals for the synthesis of nano- $\mathrm{Fe}_{3} \mathrm{O}_{4}(6$ $\mathrm{nm})$. The peak observed in the region number $3382 \mathrm{~cm}^{-1}$ was related to the vibration of $\mathrm{OH}$. This peak (around $3382 \mathrm{~cm}^{-1}$ ) was found in the FTIR spectra of all synthesized nanoparticles $(6 \mathrm{~nm}, 50 \mathrm{~nm}$, and $100 \mathrm{~nm})$. However, it was not observed in the bulk spectra (Figure 5). The FTIR spectra analysis suggests that the characteristic stretching absorption peaks at $575 \mathrm{~cm}^{-1}$ corresponding to the $\mathrm{Fe}-\mathrm{O}$ was related to the magnetite phase. Figure $5(\mathrm{Be}-h)$ shows the weight loss curves of magnetic $\left(\mathrm{Fe}_{3} \mathrm{O}_{4}\right)$ nanoparticles $(6 \mathrm{~nm}, 50 \mathrm{~nm}$, and $100 \mathrm{~nm})$ and bulk- $\mathrm{Fe}_{3} \mathrm{O}_{4}$ at different stages of surface modification. It appeared that below $200{ }^{\circ} \mathrm{C}$, the weight loss was insignificant for nano- $\mathrm{Fe}_{3} \mathrm{O}_{4}(50 \mathrm{~nm}$, 
$100 \mathrm{~nm}$ ) and bulk, which probably; presents a relative good thermal stability. The weight loss of $1.93 \%, 2.29 \%$ and $0.84 \%$ for $50 \mathrm{~nm}, 100 \mathrm{~nm}$, and bulk, respectively (Figure $5 \mathrm{~B}-\mathrm{f}, \mathrm{g}$, and $h$ ), in the region of $200-400{ }^{\circ} \mathrm{C}$, may be attributed to the release of crystal water. On the other hand, the TGA curve of the small size $(6 \mathrm{~nm})$ was very complex as shown in the Figure 5. The weight loss in the temperature range of 26$100{ }^{\circ} \mathrm{C}$ is about $4.85 \%$ corresponding to the release of physically absorbed water and the residual solvent in the sample. In the temperature range $100-450{ }^{\circ} \mathrm{C}$ there still exists a gradual weight loss of $5 \%$ which is due to the organic surface modification. There was another stage of weight loss of $1.2 \%$ observed in the temperature range of $730-830{ }^{\circ} \mathrm{C}$, which may be due to the deoxidation of $\mathrm{FeO}$. The total weight loss from the graph of synthesized nanoparticles (Figure 5) was $11.33 \%, 5.31 \%$ and $6.2 \%$, respectively for 6 $\mathrm{nm}, 50 \mathrm{~nm}$, and $100 \mathrm{~nm}$ indicating the transition phase from $\mathrm{Fe}_{3} \mathrm{O}_{4}$ to $\mathrm{FeO}$. The experiment result shows the toxicity effects of the different sizes of nano- $\mathrm{Fe}_{3} \mathrm{O}_{4}$ particles and bulk- $\mathrm{Fe}_{3} \mathrm{O}_{4}$ might depend on the chemical composition, the structure properties/ particle sizes, the concentration in the tested medium, the time of incubation, as well as the plant species.

The phytoxicity effects of $\mathrm{Fe}_{3} \mathrm{O}_{4}$ NPs $(6 \mathrm{~nm}, 50 \mathrm{~nm}, 100 \mathrm{~nm})$, and bulk were evaluated in cucumber (Cucumis sativus L ) plants grown in hydroponic conditions in terms of growth parameters, biomass production, TEM observation, antioxidant enzyme activities and MDA content. The results show that among the synthesized nano- $\mathrm{Fe}_{3} \mathrm{O}_{4}$ $(6 \mathrm{~nm}, 50 \mathrm{~nm}$ and $100 \mathrm{~nm})$, only the small size $(6 \mathrm{~nm})$ was observed to have significant inhibition on fresh and dry biomass of cucumber plants. Nano-and bulk- $\mathrm{Fe}_{3} \mathrm{O}_{4} 4$ treatments (21days) caused more oxidative stress in cucumber plants. Cucumber plants grown under lowest concentrations of $50 \mathrm{mg} / \mathrm{L}$ nano- $\mathrm{Fe}_{3} \mathrm{O}_{4}(6 \mathrm{~nm})$ were affected by a decrease in biomass and enzyme activities compared to the control. However, at higher concentration of nano- $\mathrm{Fe}_{3} \mathrm{O}_{4}$ dosage $(2000 \mathrm{mg} / \mathrm{L})$, there was significant increase in biomass and enzymatic activities (SOD and POD) respectively. The phytotoxicity effects of the different sizes of nano- $\mathrm{Fe}_{3} \mathrm{O}_{4}$ particles and bulk- $\mathrm{Fe}_{3} \mathrm{O}_{4}$ might depend on the chemical composition, the structure properties/particle sizes, the concentration in the tested medium, the time of incubation, as well as the plant species.

\section{Conclusion}

The results showed that,nano- $\mathrm{Fe}_{3} \mathrm{O}_{4}(2000 \mathrm{mg} / \mathrm{L})$ did not change the toxicity of the tested heavy metals at high concentration $(10 \mathrm{mM})$ in the seedlings of cucumber. Addition of magnetic $\left(\mathrm{Fe}_{3} \mathrm{O}_{4}\right)$ nanoparticles $(2000 \mathrm{mg} / \mathrm{L})$ in each metal solution $(1 \mathrm{mM})$, significantly decreased the growth inhibition and activated protective mechanisms to alleviate oxidative stress induced by heavy metals in the cucumber seedlings. The reducing effects of nano- $\mathrm{Fe}_{3} \mathrm{O}_{4}$ against heavy metals stress could be dependent on the increase in the enzyme activity (SOD and POD), but also their adsorption capacity of heavy metals.

Acknowledgements. This work was supported by the National Natural Science Foundation of China (No. 31271627) and Henan Provincial Research Foundation for Science and Technological Breakthroughs, China (Grant No. 152102110106). 


\section{REFERENCES}

[1] Burman, U., Garg, B. K., Kathju, S. (2004): Interactive effects of thiourea and phosphorus. - Biol. Plant. 48: 61-65.

[2] Garg, B. K., Burman, U., Kathju, S. (2006): Influence of thiourea on photosynthesis, nitrogen metabolism and yield of clusterbean (Cyamopsis tetragonoloba (L.) Taub.) under rainfed conditions of Indian arid zone. - Plant Growth Regul. 48: 237-245.

[3] Jain, T. K., Richey, J., Strand, M., Lesliepelecky, D. L., Flask, C., Labhasetwar, V. (2008): Magnetic nanoparticles with dual functional properties: drug delivery and magnetic resonance imaging. - Biomaterials 29(29): 4012-4021.

[4] Laurent, S., Forge, D., Port, M., Roch, A., Robic, C., Elst, L. V., Muller, R. N. (2008): Magnetic iron oxide nanoparticles: synthesis, stabilization, vectorization, physicochemical characterizations, and biological applications. - Chem. Rev. 39(35): 2064.

[5] Liu, J., Sun, Z., Deng, Y., Zou, Y., Li, C., Guo, X., Xiong, L., Gao, Y., Li, F., Zhao, D. (2009): Highly water-dispersible biocompatible magnetite particles with low cytotoxicity stabilized by citrate groups. - Angew. Chem. 48(32): 5875.

[6] Miguelsancho, N., Bomatímiguel, O., Colom, G., Salvador, J. P., Marco, M. P., Santamaría, J. (2011): Development of stable, water-dispersible, and biofunctionalizable superparamagnetic iron oxide nanoparticles. - Chem. Mater. 23(11): 2795-2802.

[7] Roca, A. G., Marco, J. F., Morales, M. D. P., Serna, C. J. (2007): Effect of nature and particle size on properties of uniform magnetite and maghemite nanoparticles. - J. Phys. Chem. C 111(50): 18577-18584.

[8] Shen, L. H., Bao, J. F., Wang, D., Wang, Y. X., Chen, Z. W., Ren, L., Zhou, X., Ke, X. B., Chen, M., Yang, A. Q. (2013): One-step synthesis of monodisperse, water-soluble ultra-small $\mathrm{Fe}_{3} \mathrm{O}_{4}$ nanoparticles for potential bio-application. - Nanoscale 5(5): 2133.

[9] Vinod, K., Awasthi, G., Chauchan, P. K. (2012): Cu and zn tolerance and responses of the biochemical and physiochemical system of cucumber. - J. Stress Physiol. Bi. 8(3).

[10] Xiao, L., Li, J., Brougham, D. F., Fox, E. K., Feliu, N., Bushmelev, A., Schmidt, A., Mertens, N., Kiessling, F., Valldor, M., Fadeel, B., Mathur, S. (2011): Water-soluble superparamagnetic magnetite nanoparticles with biocompatible coating for enhanced magnetic resonance imaging. - Acs Nano 5(8): 6315. 